\title{
Internationalization in entrepreneurial ecosystem and innovation system literatures: A systematic review
}

\author{
Abdollah Mohammadparast Tabas, Hanna Komulainen \& Ahmad Arslan \\ Department of Marketing, Management \& International Business \\ Oulu Business School, University of Oulu, Finland
}

\begin{abstract}
Entrepreneurial ecosystem (EE) has emerged an important new concept within the entrepreneurship and innovation research literatures. It emphasizes the supporting role of the local and regional environment for the entrepreneur and has a specific focus on high growth firms (HGFs). EE research has similarities with other literature streams specifically the innovation systems (IS) literature but the relationship between them is ambiguous, which hampers the theory development. Furthermore, it is unclear how internationalization is approached by the IS and the EE research. To fill this gap, the current paper offers a systematic literature review (SLR) of the similarities and differences between the IS and the EE concepts in the specific context of HGFs' internationalization. We analyze 67 relevant peer-reviewed journal articles. The findings suggest that, on one hand, the EE has some similarities to IS due to their emphasis on the importance of the external business environment. On the other hand, EE is strongly centered on individual entrepreneurs and high growth ventures giving less importance to the government's role, which has been the case in IS literature. We also found that the internationalization of HGFs to be an under-researched area of research in this domain, which requires further empirical analysis.
\end{abstract}

Keywords: Entrepreneurial ecosystem, high growth firms, innovation systems, internationalization, systematic literature review 


\section{INTRODUCTION}

The role of the external business environment for entrepreneurial innovation (Autio, Kenney, Mustar, Siegel, and Wright, 2014) and firm growth (Cassia, Colombelli, and Paleari, 2009) is increasingly gaining researchers' attention. This has led to the emergence of new concepts such as the entrepreneurial ecosystems (EE) perspective, which has some similarities to existing concepts particularly innovation systems (IS). According to the well-known definition by Stam and Spigel (2016 p. 1), the EE are "a set of interdependent actors and factors coordinated in such a way that enables productive entrepreneurship within a particular territory". The existing literature within the entrepreneurship and innovation research focuses either on the IS, clusters or the EE, but there is no common understanding about the differences and similarities of these concepts. Hence, exploring the similarities and differences is IS and the EE can help to establish a more rigorous theoretical foundation of the EE. It should further be noted that the EE research strongly focuses on HGFs i.e. high growth firms (Spigel and Harrison, 2018; Stam, 2015). HGFs defined as enterprises "with average annualized growth greater than $20 \%$ per annum, over a three-year period, with a minimum of 10 employees at the beginning of the growth period" (OECD, 2008: 61). HGFs are increasingly important for the economies as they contribute to productivity (Du \& Temouri, 2015), undertake high level of innovations (Anyadike et al., 2009 ; Coad et al., 2014) and enhance economic competitiveness (Brown, Mason, and Mawson, 2014; Terjesen, Bosma, and Stam, 2016). Furthermore, they play a significant role in employment generation (Brown and Mawson, 2016). Many HGFs grow by entering new geographical markets and, compared to other types of firms, they tend to internationalize significantly and rapidly (Brown and Mawson, 2016). However, even though an international expansion is a significant way to exploit external market opportunities and enhance HGFs' growth (Brown and Mawson, 2016; Velt, Torkkeli, and Saarenketo, 2018), it is unclear how internationalization is approached by extant IS and EE research.

To address these gaps in the existing knowledge, we examine a sizable body of research that has been conducted from 1993 to 2018 on the IS and the EE by means of a systematic literature review (SLR) (Tranfield, Denyer, and Smart, 2003). This SLR is expected to offer insights to the differences between both literature streams and understanding their views on HGFs' internationalization. The SLR undertaken is based on the review peer-reviewed journal articles on the EE and the IS on indexed in the Scopus and Web of Science depositories. The current paper aims to achieve four goals with this SLR. Firstly, we review the literature related to the EE and the IS with the aim of defining both concepts in detail. Secondly, we overview the similarities and differences between the two concepts to see whether they 
overlap and how. Thirdly, we explore how internationalization is associated with EE and the IS approaches. Finally, we suggest an agenda for future research based on the gaps in the extant literature.

Our paper highlights that there is no consensus on a specific definition or a theoretical framework for EE. Hence, more research is needed to strengthen the conceptual foundations of the EE and developing a specific theory focusing explicitly on it. In addition, there is a need for empirical studies complementing the extant, mainly conceptual research. We also found that HGFs' internationalization in context of EE is one of the key topics requiring further empirical research, as this specific topic has been limitedly analyzed so far. Our paper contributes to extant EE, IS and internationalization literature by being one of the first studies to specifically undertake SLR with specific focus on HGFs and their internationalization. We also complement the work by some prior studies which have tried to address both EE and IS by specifically bringing in HGF specific discussion in this context.

The rest of the paper is organized as follows. The next section offers details on SLR by presenting discussion of the methodology, research question formulation, how studies were located and other aspects of the systematic review in detail. After that study findings are presented. The paper concludes with presentation of theoretical and practical implications as well as discussion on limitations, and future research directions.

\section{SYSTEMATIC LITERATURE REVIEW}

\subsection{Methodology}

In this paper, we follow SLR approach according to the guidelines suggested by Tranfield et al. (2003), which is most quoted in the area of social science (e.g. Wong, Skipworth, and Godsell, 2012; Costa, Soares, and Sousa, 2016). Using SLR approach helps the researchers to summarize existing evidence according to an explicit, rigorous, and transparent step-wise process (Tranfield et al., 2003; Mallett, et al., 2012). In this paper we follow the five-step approach of Denyer and Tranfield (2009), which consists of (1) the question formulation, (2) locating studies, (3) study selection and evaluation, (4) analysis and synthesis, and (5) reporting and using the results.

\subsection{Question formulation}

A well-crafted research question is crucial for the study direction (Wong et al., 2012). Following the CIMO (i.e. context, intervention, mechanism, and outcomes) question formulation approach suggested Denyer, Tranfield and Van Aken (2008), the paper attempts to answer the questions related to the view 
of the EE and the IS approaches on HGFs' internationalization. The context of the study (C) is the EE and the IS perspective; the interventions (I) are the convergence of the IS and the EE dynamics for the HGFs' internationalization; the mechanism (M) of interest is to conceptually analyze the EE and the IS literatures; and the outcome $(\mathrm{O})$ is a clearer understanding of the boundaries and the roles of the EE and the IS for the HGFs' internationalization. Based on the CIMO logic, our SLR addresses following questions:

RQ1. How are IS and EE defined in the extant literature?

RQ2. How do the IS and the EE perspectives conceptually overlap?

RQ3. How the internationalization of HGFs is addressed within the EE and the IS perspectives?

By answering these specific questions, we can advance the understanding of the essence and overlaps of the IS and the EE literatures in their view on the internationalization of the HGFs.

\subsection{Locating studies}

Identifying relevant literature is very important for SLR. Hence, using the appropriate academic search engine and the right search strings are very important. We used two search databases, Scopus and the Web of Science, which are mostly used by researchers for literature search. We believe that these two databases cover the field under investigation well. Initially, more than 18 key terms and synonyms were created through a brainstorming exercise and, in order to ensure the validity of the search strings, several pre-tests were conducted to check the search results. During the identification process, a database expert with significant experience in offering assistance with SLRs was consulted to ensure that the search strings and the databases being used were optimal. Afterwards, six search strings were selected from the original list as shown in Table 1. The six strings generated 3,799 results in the Scopus database and 3,842 results in the Web of Science.

Table 1

Search strings and the number of results

\begin{tabular}{llll}
\hline Search engine & Search strings & Search field & Result \\
\hline Scopus & $\begin{array}{l}\text { (entrep* AND ecosystem*) } \\
\text { OR (entrep* system*) AND } \\
\text { (innovat* AND system*) }\end{array}$ & $\begin{array}{l}\text { Article title, } \\
\text { abstract, } \\
\text { keywords }\end{array}$ & 3,799 \\
& $\begin{array}{l}\text { (entrep* AND ecosystem*) } \\
\text { OR (entrep* system*) AND }\end{array}$ & Topic & 3,842 \\
& $\begin{array}{l}\text { (innovat* AND system*) } \\
\text { (innoncen }\end{array}$ & & \\
\hline
\end{tabular}




\subsection{Inclusion and exclusion criteria}

In the next step we conducted two rounds of inclusion and exclusion exercise (see Figure 1 for a detailed description of the process). For the Scopus database, the 3799 results were limited to years 1993 to 2018 because in the early 1990s the more standard references to national system of innovation were introduced in three edited books by Lundvall (1992), Nelson (1993), and Edquist (1997). In addition, the results were limited to certain subject areas (business, management and accounting, social sciences, economics, econometrics and finance), restricted to two document types (articles and reviews) and narrowed down to English language.

The result of the first round of inclusion and exclusion was 1593 articles. In the second round, we focused on the concepts of "entrepreneurial ecosystems" and "innovation systems" and searched for articles having both as key concepts to be able to answer the RQ1 and the RQ2. We checked the title, keywords and abstract of the articles generated in the first round and excluded the pieces that were not relevant to the present study. The relevance was confirmed by checking each article and ensuring that it was from the field of business and management (not, for example, from the IT and information systems that are out of the scope of this study). At the same time, we checked whether the articles focused on the internationalization of the HGFs to be able to answer the RQ3. After the second round, we examined 110 full-text articles. This process reduced the number of relevant articles to 57. The results were exported to a citation management software package (Mendeley) after removing the duplicates. In the end, a backward snowballing, i.e. a strategy using references of papers to find relevant studies (Wohlin, 2014), was conducted, enlarging the number of studies to 67 for the purpose of SLR. 


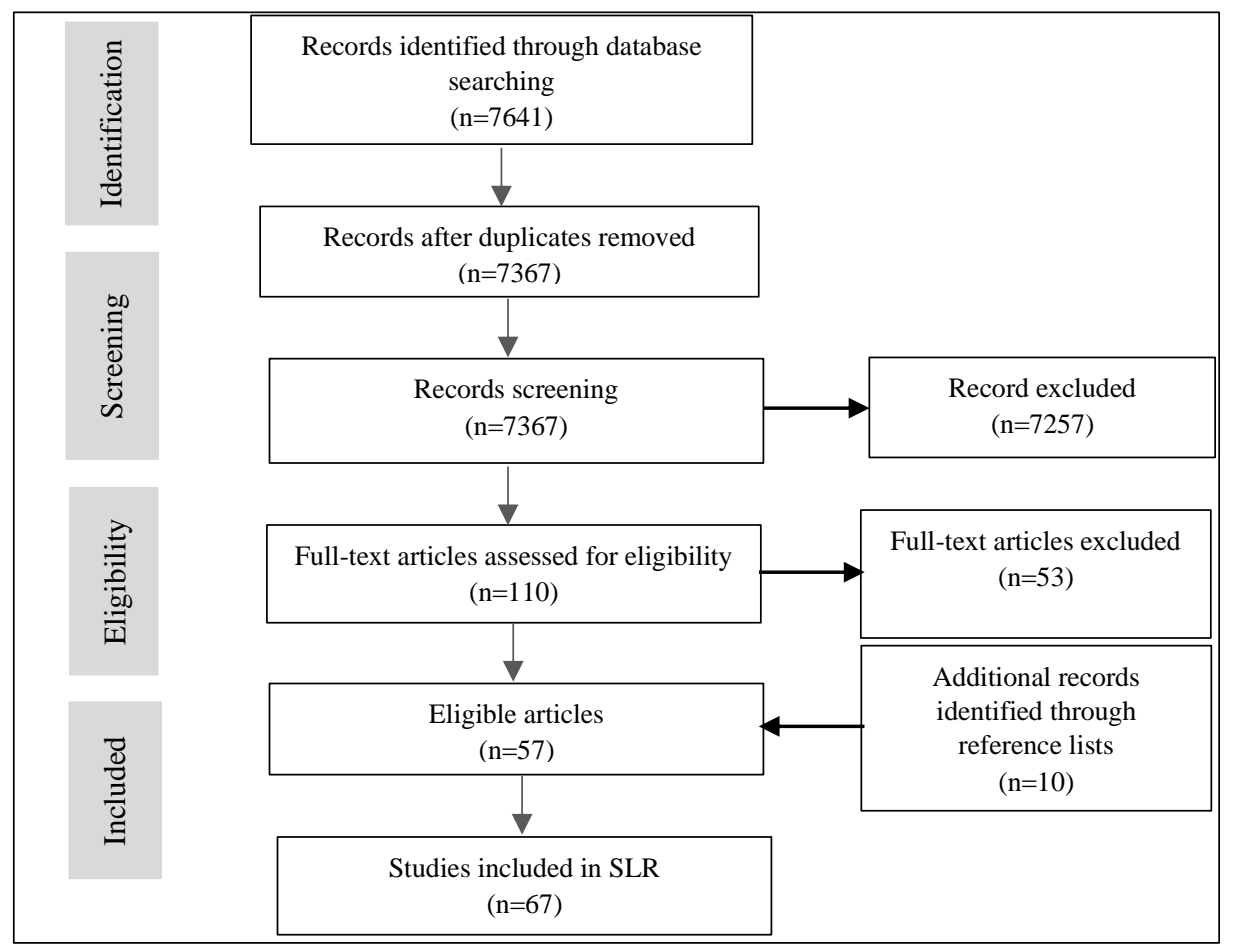

Figure 1. Description of the inclusion and exclusion process (adapted from Moher et al., 2009)

\section{FINDINGS}

The articles were categorized into three groups according to their subject matter, namely, the IS (24 articles), the EE (34 articles), and those considering the similarities and differences between the IS and EE approaches ( 9 articles). Table 2 below presents the articles together with the category they belong to, plus a summary of the findings of each article in question. After that, we will discuss the methodology used in the articles, their research topics, publication years and journals in a more detail. 


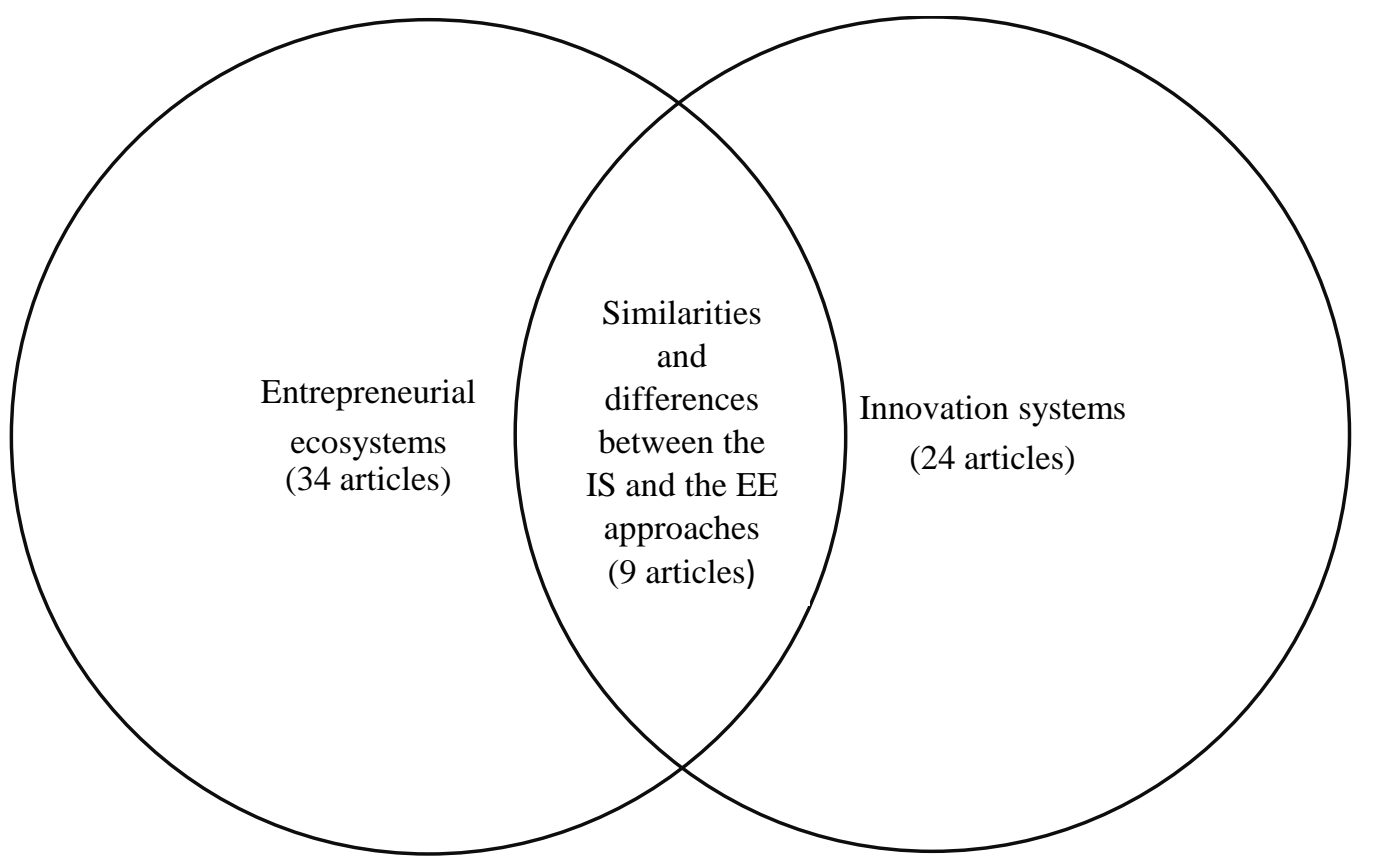

Figure 2. Mapping the intersection of the EE and IS approaches 
Table 2: SLR Studies, frameworks used and key contributions

\begin{tabular}{l}
\hline References \\
\hline 1. Acs, Audretsch, and \\
Lehmann (2016) \\
2. Acs, Autio, and Szerb \\
(2014) \\
3. Acs, et al (2017) \\
4. Alvedalen and Boschma \\
(2017) \\
5. Asheim and Coenen \\
(2005) \\
6. Asheim and Isaksen \\
(2002) \\
7. Asheim, Smith, and \\
Oughton (2011)
\end{tabular}

\section{Theory/Framework Topic Country of \\ research}

Key contributions

National innovation IS N/A Summarizes the state of current research on national IS.

$$
\text { systems }
$$

National system of

entrepreneurship

$\mathrm{EE} \&$
IS

Entrepreneurial theory

EE \&

IS

Entrepreneurial

ecosystem

Knowledge based

view

Regional innovation systems

Regional innovation

systems

Regional

8. Audretsch and Belitski (2017)

9. Auerswald and Dani (2017)

10. Autio et al (2014)

11. Autio et al (2018)

12. Berger and Kuckertz (2016)

13. Brown and Mason

(2017)

14. Brown and Mawson

(2016)

15. Bruns et al., (2017)

16. Carayannis et al (2018)

17. Carayannis, Provance, and Grigoroudis (2016) 18. Carlsson (2006)

19. Cassia, Colombelli, and Paleari (2009)

20. Cohen (2006)

21. Colombo et al (2019)

entrepreneurship \&

innovation system

Adaptive life cycle

Entrepreneurial

innovation

Entrepreneurship

theory

Women's

entrepreneurship " $5 \mathrm{M}$ " framework

Entrepreneurial

ecosystems

Internationalization

process theory

Entrepreneurial

ecosystems

Simple theory

Quintuple helix

Innovation system

Knowledge spillover theory

Sustainable

entrepreneurial

ecosystem

Entrepreneurial

22. Cooke (2001a)
Regional innovation

system
Global Introduces the concept of the National System of Entrepreneurship (NSE) and provides a method to characterize NSEs in a way that capture key systemic properties.

N/A Distinguishes the EE concept from other theories within the regional innovation development and strategic management literature and suggests avenues for further research.

Identifies several weaknesses in EE literature and proposes suggestions for future research.

N/A Offers a link to the literature on 'varieties of capitalism' and national business systems.

Norway Discusses the significance of a multilevel approach to innovation systems and technology transfer as firms in regional clusters exploit both place specific local resources as well as external, world-class knowledge respectively to strengthen their competitiveness

N/A Provides an assessment and synthesis of the regional innovation paradigm

Europe

Contributes methodologically and suggests the development of metrics to determine the strengths and weaknesses of a regional system of entrepreneurship and the relationship between each domain of the systems.

USA Advances understanding of the role of entrepreneurship in developing essential capabilities and networks that drive the sustainable development of regions and presents an empirical framework that can be utilized for assessing the vibrancy of a regional EE.

N/A Develops a framework of entrepreneurial innovation and context. With the references to this framework, the attributes of national system of innovation, entrepreneurship, and entrepreneurial innovation are compared.

Highlights the similarities and differences of EE from other cluster types such as knowledge clusters, regional systems of innovation and innovative milieus. Proposes a structural model of EE.

Global Connects EE with female entrepreneurship and presents two configurations explaining a high proportion of female founders in successful startup ecosystems.

N/A Sets out a preliminary taxonomy of different archetypal ecosystems and concludes that EE are a highly variegated, multi-actor and multi-scalar phenomenon, requiring bespoke policy interventions.

UK Studies the internationalization process of high growth firms.

Europe Develops a method to measure EE.

N/A Examines the process of new venture creation by focusing on the effects caused by the interactions between entrepreneurs and institutions from a knowledge creation, dissemination and absorption perspective.

Profiles the nature and dynamics of quadruple helix IS framework consisting of government, university, civil Profiles the nature and dynamics of quadruple helix IS framework consisting
society, environment and industry, which enables regional co-appetitive EE. society, environment and industry, which enables regional co-app
Highlights the literature on internationalization with respect to IS.

Finds that both universities' knowledge input and output in a specific region positively influence the rate of growth of entrepreneurial companies in the early stages of the life cycle.

Canada Focuses on the community perspective aiming towards innovation and explains how community culture, infrastructure as well as formal and informal networks can contribute to sustainable EE.

N/A Creates understanding of the entrepreneurial governance issues including theoretical and conceptual understanding of ecosystems' governance models and their evolutionary paths, governance structures and boundaries.

Presents a systematic account related to the idea of regional innovation system (RIS). 
24. Cook and Leydesdorff (2006)

25. Cooke, Uranga, and

Etxebarria (1997)

26. Cowell, Lyon-Hill, and Tate (2018)

\section{Etzkowitz (2003)}

28. Fernández, Blanco, and Cuadrado (2015)

29. Freel (2003)

30. Goswami, Mitchell, and Bhagavatula (2018)

31. Isenberg (2010a)

32. Isenberg (2011b)

33. Iyer (2016)

34. Kshetri (2014)

35. Lundvall (1998a)

36. Lundvall (2007b)

37. Lundvall et al (2002)

38. Mack and Mayer (2016)

39. Malecki (2018)

40. Maroufkhani et a

(2018)

41. Marques, Caraça, and

Diz (2006)

42. Miller and Acs (2017)

43. Muldoon, Bauman, and Lucy (2018)

44. Nambisan and Baron

(2013)

45. Nicotra et al (2018) advantages theory

Regional innovation

$$
\text { systems }
$$

Social network theory

Triple helix

Open Innovation

Network theory of innovation

Entrepreneurial

cognition theory

Entrepreneurial

ecosystems

Entrepreneurships

Sectoral system of Innovation

Entrepreneurship theory

National system innovation

National system innovation

National system innovation

Evolutionary dynamics

Entrepreneurship \& entrepreneurial ecosystems

Entrepreneurial

ecosystems

Triple helix

Ecosystems

Social capital \& Resource-based view Entrepreneuria innovation Cause-effect theory
Global \& pain

\section{Indi}

N/A

N/A

India

Estonia \& Kore

N/A

N/A

N/A

USA
Concludes that the idea of "enterprise ecosystems" or, if preferred "entrepreneurial ecosystems", further underlines the potential of new opportunities for developing not only the "virtues" but also the "value of variety".

Develops an understanding of how regional development leads to constructed advantage in knowledge-based economies.

Develops the concept of regional innovation system (RIS)

Identifies the differing requirements of entrepreneurs within an ecosystem and the unique dynamics of ecosystems with a mix of both urban and rural features.

Explicates the development and sources of triple-helix (university-industry-government) and formats emerging academic entrepreneurial university.

Conceptualizes and relates the features of EE, business services and open innovation within the process of business incubation.

Posits that due to the spatial distribution of firm linkages, it appears that increasing firm size and export propensity are positively associated with external linkages at a higher spatial level.

Investigates underpinnings of the EE by highlighting the role accelerators can play in affecting performance outcomes related to venture success or failure as well as the development of the regional EE.

Defines ecosystem as a dynamic, self-regulating network of many different types of actors.

Introduces nine prescriptions for creating successful EE.

Highlights how the technology strategy of entrepreneurs plays a critical role in initiating and sustaining the sectoral system of innovation.

Finds major similarities as well as differences between the key ingredients of the two entrepreneurial economies, namely Estonia and South Korea.

Highlights the importance of interaction, learning and the role of nation-based institutions in innovation performance.

Extends current understanding of national innovation systems and the importance of knowledge and learning as the basis for innovation.

Provides a historical overview on the development of the IS concept

Develops an evolutionary framework for determining various stages of the EE development.

Traces the emergence of the EE concept.

Provides a descriptive analysis about EE and extends the Isenberg's (2011) model of EE by adding crowdfunding as a contributing element for the EE.

Discusses how regional dynamics of innovation and entrepreneurship are promoted with the multiplicity of a trilateral relationship between university, industry and government.

Suggests that the open, innovative American frontier that closed at the end of the twentieth century has re-emerged in the entrepreneurial economy at the U.S. campus.

Implies that the best strategy for an entrepreneur would be to balance between trust/distrust and social network ecosystems while making decisions.

Extends the current theory concerning the potential role of self-regulatory processes in entrepreneurship to successfully balance requirements set by the ecosystem leader with the goals of their own ventures. Develops a framework to measure the causal effects of eco-factors on eco-output. 
46. Oh et al (2016)

47. Öner and Kunday

(2016)

48. Pittz and Hertz (2018)

49. Qian and Acs (2013)

50. Roundy (2017a)

51. Roundy (2017b)

52. Roundy, Bradshaw an Brockman (2018)

53. Scaringella an

Radziwon (2018)

54. Schøtt and Jensen

(2016)

55. Sharif (2006)

56. Sohn and Kenney

(2007)

57. Spender et al (2017)

58. Spigel (2017)

59. Spigel and Harrison (2018)

60. Stam (2015)

61. Suresh and Ramraj

(2012)

62. Theodoraki,

Messeghem, and Rice

(2018)

63. Thompson, Purdy, and

Ventresca (2018)

64. Vargo, Wieland, and

Archpru (2015)

65. Velt et al (2018)

66. Yoon et al (2015)

67. Zahra and Nambisan
Social network

Absorptive capacity theory of knowledge spillover

ntrepreneurship

Institutional logic

Social

entrepreneurship

Complex adaptive

$$
\text { systems }
$$

Ecosystems

Network

National innovation system

Cluster \& regional

innovation systems

Open Innovation

Entrepreneurial theory

Process-based

perspective

Entrepreneurial ecosystem

Bottom of the pyramid

Social Capital

Field theory

Service-ecosystem View

Entrepreneuria

ecosystems

Social capital

Entrepreneurship theory
USA \& Europe USA

Estonia

Korea \&

Taiwan

N/A
Discusses various types of IS.

Demonstrates that opportunity-based entrepreneurship has a positive impact on the growth expectation of entrepreneurs.

Explores the function and structure of entrepreneurship center in EE.

Investigates regional variations in knowledge-based entrepreneurial activity and introduces a system approach to entrepreneurship building upon the absorptive capacity theory.

Develops an understanding of EE and explores the role of institutional logics and hybrid support organizations on ecosystem formation, functioning and structure. Explains the cultural values that direct the ecosystem participants. Finds that EE and social entrepreneurs mutually affect each other and that social entrepreneurs can shape the EE by influencing the heterogeneity of ecosystem participants, gathering attention for the ecosystem, and increasing its attractiveness for stakeholders.

Provides a framework for analyzing EE as complex adaptive systems.

Identifies and discuss the four main types of ecosystems -business, innovation, entrepreneurial, and knowledge ecosystems - and indicate the presence of other transversal concepts

Finds a positive relationship between firms' networking and firms' product and process innovations.

Offers a historical overview of the development of the national innovation concept.

Explores the relationship between university, industry and high technology clusters in Korea and outlines the weaknesses of Korean University research institutes in terms of their inability to develop innovative clusters. Summarizes the existing empirical and conceptual insights related to the interaction between startups and open innovation.

Examines the attributes constituting the EE, the relationship between them and their influence on the competitiveness of new ventures.

Develops a process perspective on EE, in which ecosystems are viewed as ongoing processes of the development. Explores entrepreneurial resources such as human and financial capital, entrepreneurial know-how, market nowledge, and cultural attitudes.

Conceptualizes the EE and distinguishes the concept from other concepts such as clusters and regional innovation systems. Provides a process-based framework to study how ecosystems develop, evolve, and deliver benefits to entrepreneurs.

Highlights eight factors comprising ecosystem that motivate/constraint the entrepreneurs to start entrepreneurship journey.

Finds that three dimensions of social capital (structural, cognitive and relational) are relevant to the effective functioning of the university-based $\mathrm{EE}$

Suggests a bottom-up activity-rich view of ecosystem formation and social interaction considered as important sources for ecosystem formation.

Argues that maintenance, disruption and changes in institutions are central for both technology and market innovations.

Identifies seven systemic elements as the main factors impacting the launch, and ten elements impacting the growth of born global start-ups.

Explains the role of social capital in vitalizing entrepreneurship in regional innovation systems and provides policy implications for latecomer governments by documenting different approaches to make their regional innovation system more entrepreneurial.

Explores the behavior of established companies, corporate ventures and independent ventures in different ecosystems. 


\subsection{Methodology used in the articles}

Figure 3 presents the summary of methodology used by articles analyzed in our SLR. The articles were categorized into four categories: quantitative, qualitative, qualitative and quantitative (i.e. mixed) and reviews, following the classification by Costa et al. (2016). Most of the articles were qualitative (46), followed by quantitative (11), review (6) and mixed (4) types of articles. Based on our SLR, existing research mostly consists of qualitative and conceptual studies. Thus, more empirical research especially quantitative and mixed methodology studies are needed to a gain further and better understanding.

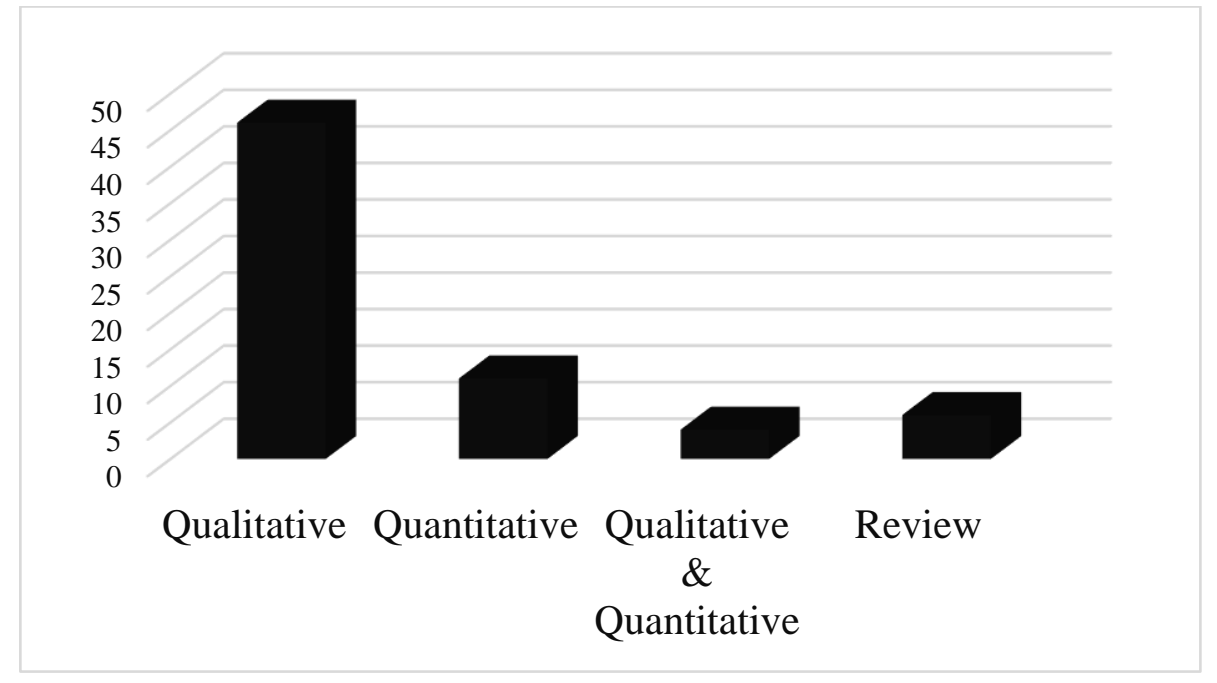

Figure 3. Classification of the articles

\subsection{Research topic exploration}

The keywords proposed in the reviewed papers illustrate the main topics studied. Figure 4 represents a cloud, where the size of the keywords is proportional to the number of times each keyword appears in the selected papers. From the cloud it is possible to note that the top keywords are 'entrepreneurial', 'innovation', 'entrepreneurship', 'ecosystem', 'business', 'knowledge', 'ecosystems', 'entrepreneurs', 'regional', 'development', 'growth', 'policy', and 'systems. This shows that 'entrepreneurial', 'innovation' and 'ecosystem' are the most frequently used keywords, which illustrates the predominance of these subjects. In IS literature the most popular words are innovation, institution, government, university, and knowledge, while in EE focused studies entrepreneurship, policy, system, and growth were the most popular keywords. Our analysis also reveals that since the IS research stream emerged towards the end of the twentieth century, there are numerous research articles related to it. On the other 
hand, the concept of EE started to become popular after seminal studies of Isenberg (2010), Feld (2012), and Mason and Brown (2014). Since then its growth as an independent research stream has been exponential. Finally, the literature review shows that internationalization is not represented in the cloud of keywords. In other words, it has not been discussed significantly in this context, despite its importance.

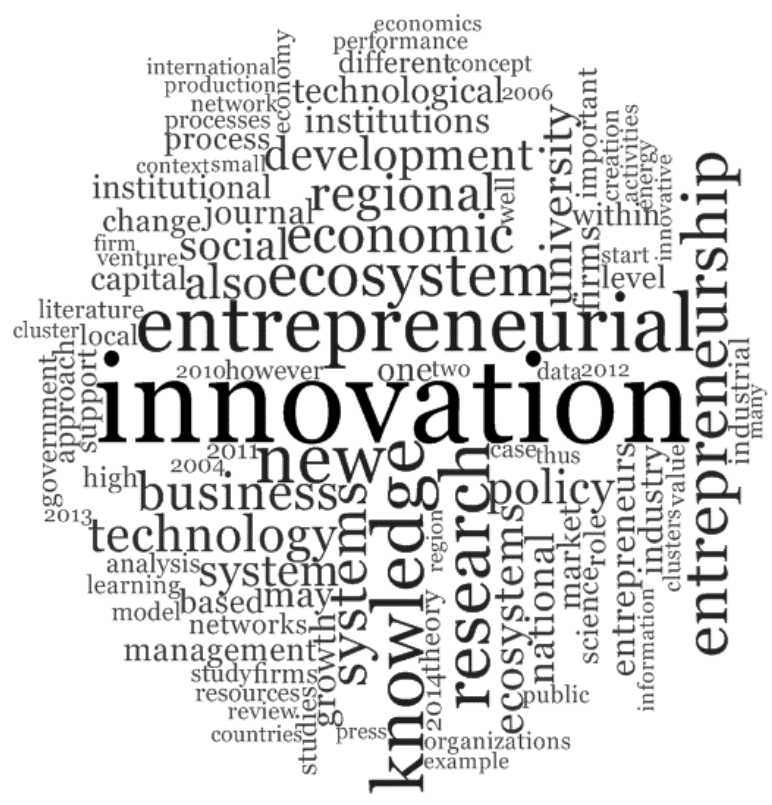

Figure 4. Cloud of keywords

\subsection{Article classification by the year of publication}

The analysis of frequency of the selected papers makes it clear that the subject of this study and the evidence bases are relatively recent. Figure 5 shows the yearly distribution of the articles; until 2003 only a few have been published about the IS and the EE and until 2010, most of the work published focused on the IS. The landmark work of Isenberg (2010) defining the determinants of the EE was the starting point that drew the attention of scholars towards the EE concept. As of 2015, our search retrieved at least three papers per year on the topic of our interest, with the maximum of 14 paper in 2017. 13 papers were written on this topic in 2018. Thus, the topic is well entrenched by now and has gained the attention of a wide range of business and management researchers. 


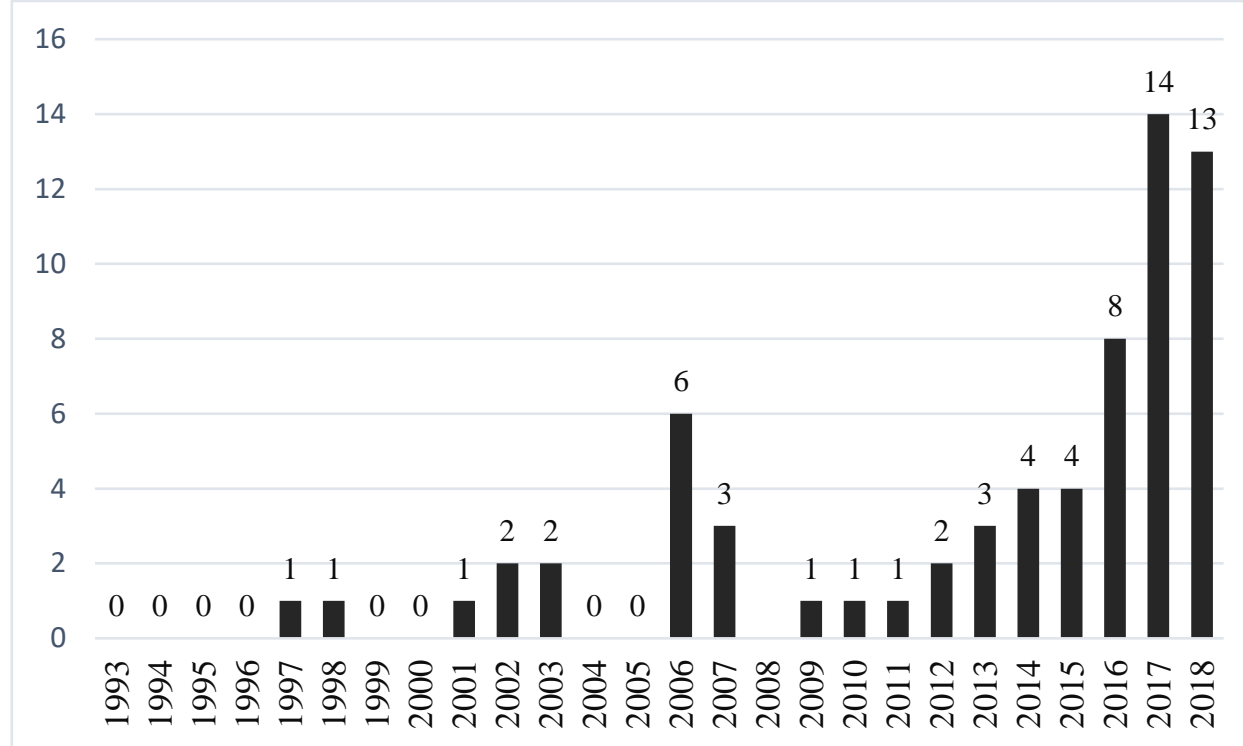

Figure 5. Yearly distribution of the articles

\subsection{Article classification by the journal name}

Table 3 shows the names of the key journals in which the selected 67 peer-reviewed articles were published. More than half of the publications are in Small Business Economics (15\%), Research Policy (12\%), Journal of Technology Transfer (8\%), Journal of Enterprising Communities (8\%), Technological Forecasting and Social Change (6\%), and Strategic Entrepreneurship Journal (6\%). The percentage of the remaining articles from 33 journals were not above 5\%. For instance, Journal of Business Research recorded 3\% while World Development and other journals recorded 2\%. Small Business Economics is at the top of the list with 10 articles and $15 \%$. This can be traced to the broad scope of the journal including entrepreneurial characteristics, new ventures, family firms, small and medium-sized firms, new venture creation and innovation. In addition, Journal of Technology Transfer recorded $8 \%$ of all the articles as it covers an extensive range of publications related to the practice of technology transfer, which is closely connected to innovation. Likewise, Research Policy recorded $12 \%$ due to its wide-ranging scope of diverse topics related to this research. It can be concluded, that most of the journals are quite multidisciplinary in nature, which explains their presence in this study as well as highlights multidisciplinary roots of EE concept. 
Table 3: Key journals

\begin{tabular}{|l|c|c|c|}
\hline Journals & $\begin{array}{l}\text { No. of } \\
\text { articles }\end{array}$ & Percentage & Types of papers reviewed \\
\hline Small Business Economics & 8 & $15 \%$ & $\begin{array}{c}\text { Qualitative, } \\
\text { Quantitative, \& } \\
\text { Review }\end{array}$ \\
\hline Research Policy & 7 & $12 \%$ & $\begin{array}{c}\text { Qualitative, } \\
\text { Quantitative, \& } \\
\text { Review }\end{array}$ \\
\hline Journal of Technology Transfer & 5 & $8 \%$ & $\begin{array}{c}\text { Qualitative, \& } \\
\text { Quantitative }\end{array}$ \\
\hline $\begin{array}{l}\text { Journal of Enterprising Communities: } \\
\text { People and Places in the Global Economy }\end{array}$ & 5 & $8 \%$ & $\begin{array}{c}\text { Quantitative, } \\
\text { Review, } \\
\text { Q Mixed methods }\end{array}$ \\
\hline $\begin{array}{l}\text { Technological Forecasting and Social } \\
\text { Change }\end{array}$ & 4 & $6 \%$ & $\begin{array}{c}\text { Qualitative, } \\
\text { Quantitative, \& } \\
\text { Review }\end{array}$ \\
\hline Strategic Entrepreneurship Journal & 4 & $6 \%$ & $\begin{array}{c}\text { Qualitative } \\
\text { Qualitative }\end{array}$ \\
\hline Journal of Business Research & & $3 \%$ & Qualitative \\
\hline Harvard Business Review & 2 & $3 \%$ & Qualitative \\
\hline Entrepreneurship theory and Practice & 2 & $3 \%$ & \\
\hline
\end{tabular}

*Impactor Factor Based on Web of Science Database

\section{DISCUSSION AND CONCLUSIONS}

The current SLR is one the first attempts to organize the scientific knowledge related to the similarities and differences between the IS and the EE concepts and their approach towards HGFs' internationalization. To the best of our knowledge, there is no other SLR comparing the EE and the IS concepts that sheds light on the critical premises of both research streams and reveal their inter-related relationship as well as approach to internationalization. The SLR methodology proved to be a useful tool for moving away from descriptive reviews of the literature, with contributions including the synthesis of main findings of the literature, the identification of knowledge gaps, and the establishment of a basis for the future research. We present conclusions based on our SLR's implications as well as limitations, future research directions as follows. 
A key theoretical implication of our SLR comes from the fact that it has highlighted the lack of consensus on definitions of EE and IS in literature. As illustrations of usable definitions, we found Nelson's (1993) definition of the national innovation system defining it as "a set of institutions whose interaction determines the innovative performance of national firms" (p.4). In addition, Qian, Acs, and Stough (2012) emphasize that the IS literature explores how networks of actors are involved in the generation, diffusion and use of innovations, and how institutions influence these interaction patterns (see also Alvedalen \& Boschma, 2017). When defining the EE, we found Mason's and Brown's (2014) definition very comprehensive and detailed as they define entrepreneurial ecosystem as "a set of interconnected entrepreneurial actors (both potential and existing), entrepreneurial organizations (e.g. firms, venture capitalists, business angels, banks), institutions (universities, public sector agencies, financial bodies) and entrepreneurial processes (e.g. the business birth rate, numbers of high growth firms, levels of 'blockbuster entrepreneurship', number of serial entrepreneurs, degree of sellout mentality within firms and levels of entrepreneurial ambition) which formally and informally coalesce to connect, mediate and govern the performance within the local entrepreneurial environment" (p.5). Hence, it can be argued that EE and IS definitions are rather context specific, thereby offering future researchers a possibility to add dimensions and aspects relevant to their theoretical and analytical focus while using these concepts.

Our SLR also reveals that IS by itself is a well-established concept since the end of past century (Lundvall, 2007), but EE has received increasing attention from scholars and practitioners only recently (e.g. Roundy, Bradshaw, \& Brockman, 2018). In addition, the reviewed studies show that EE and IS have some similarities as they both discuss the potential of external business environment but there is a chasm that demarcate their common interest (Stam, 2015). The key difference is that from the EE perspective the entrepreneurs are the key actors in the system ( e.g. Isenberg, 2010; Isenberg, 2014; Spigel \& Harrison, 2018) while in IS; enterprises, government agencies, and university are the main players (Lundvall, 2007; Spigel \& Harrison, 2018). The state (national government) has overall responsibilities in IS perspective for the formulation of policy and strengthening the infrastructure for learning and innovation; while state plays a more supportive role in case of EE. Another key difference between EE and IS literatures is that EE literature is strongly focused on HGFs (e.g. Stam, 2015) and emphasizes this type of entrepreneurship as highly important source of innovation, productivity, growth and employment (e.g. Manson \& Brown, 2014). HGFs receive support from EE in form of networking possibilities (Spigel, 2017), identification of untapped market niches (e.g. Spigel \& Harrison, 2018), supporting proactive attitude to international markets (e.g. Rong, Wu, Shi, \& Guo, 2015), and attracting financial resources, 
human capital and know-how (e.g. Audretsch et al., 2019). Understanding of these differences are expected to be helpful for theory building efforts specific to both EE and IS.

We also found that although the EE literature focuses on HGFs, it has addressed their internationalization rather limitedly. This is a surprising finding, since international growth is seen as highly important specifically for these types of ventures (Brown \& Mawson, 2016). Based on our SLR, there were only two articles specifically discussing this topic; the study of Brown \& Mawson (2016) that explores the internationalization process of HGFs in Scotland, and the study of Velt et al. (2018) that examines the importance of EE for the internationalization of born global firms in Finland \& Estonia. These papers do not examine, however, the EE role in HGF's internationalization. Thus, we could not find any study explicitly focusing on how the EE enables the HGF to internationalize. This is an important gap in the current understanding and requires further empirical research. Understanding different aspects and strategies associated with use of EE during internationalization is very important for HGFs, which are the main focus of EE research. Moreover, how to utilize the supportive community as well as the surrounding economic environment in the attempts to gain growth through internationalization is a key unanswered question here. Therefore, more empirical research is needed on this subject in order to specifically theorize EE role in internationalization.

Along with theoretical implications, the current SLR does offer some managerial and policy implications as well. Firstly, it highlights the importance EE for managerial audience especially in context of HGFs and internationalization. Managers of SMEs and particularly micro enterprises that tend to lack resources should view EE as particularly being useful as they can offer access to business intelligence, financial resources and collaborators for expansion. Furthermore, the EE concept offers these managers a broad understanding of the role of the different actors and helps the government to come up with more entrepreneurial-oriented policies.

A key implication for policy makers is to look beyond just offering startup support to SMEs and micro enterprises and take the ecosystem view while devising policies. The policymakers need to design different policy approaches to enterprise development due to increasingly complex and changing economic environment. The EE approach focuses on HGFs that are economically more important for the countries (e.g. Lee, 2014; Stam, 2015) because these HGFs are an important source of job creation (e.g. Lopez-Garcia \& Puente, 2012; Mason \& Brown, 2013; Lee, 2014), as well as depict high level of productivity (e.g. Daunfeldt, Elert, \& Johansson 2014; Du \& Temouri, 2015). Hence, focusing on HGFs 
operating within an EE will help policy makers to make the relationship with business development and growth more strategic and long-term with tangible positive outcomes for wider society.

Our paper does have some limitations. First, this study focuses on two concepts, namely IS and EE, without paying attention to other useful concepts like clusters and innovation milieus. Second, the study only utilized two databases, SCOPUS and Web of Science, while databases such as EBESCO, Google Scholar or Science Direct were not included in this study. Third, this study only used peer-reviewed papers while other intellectual pieces such as book chapters and business reports were not included. Nevertheless, despite limitations, our paper paves the way for the future research that can build on it and explore more databases and other types of publications. The future research could also carry out more

empirical research since conceptual papers dominate the existing literature. Furthermore, this study sighted only one article studying female entrepreneurship in startup ecosystems indicating that there is a need for future researchers to examine issues related to women in entrepreneurship ecosystems research. Finally, most of the articles in this research area tend to focus on developed countries' context. Therefore, the future studies could consider examining EE in other contexts, such as in Africa, Asia and Latin America.

\section{REFERENCES}

Acs, Z. J. et al. (2016). 'National systems of entrepreneurship', Small Business Economics, 46(4), pp. 527-535. doi: 10.1007/s11187-016-9705-1.

Acs, Zoltán J. et al. (2017). 'National systems of innovation', Journal of Technology Transfer, 42(5), pp.997-1008. doi: 10.1007/s10961-016-9481-8.

Acs, Zoltan J. et al. (2017). 'The lineages of the entrepreneurial ecosystem approach', Small Business Economics, 49(1), pp.1-10. doi: 10.1007/s11187-017-9864-8.

Ács, Z. J., Autio, E. and Szerb, L. (2014). 'National Systems of Entrepreneurship: Measurement issues and policy implications', Research Policy, 43(3), pp. 476-494. doi: 10.1016/j.respol.2013.08.016.

Alvedalen, J. and Boschma, R. (2017). 'A critical review of entrepreneurial ecosystems research: towards a future research agenda', European Planning Studies, 25(6), pp.887-903.

Anyadike-Danes, M. et al. (2009). 'Measuring business growth: high growth firms and their contribution to employment in the UK', Economic Research Institute of Northern Ireland, Monograph, (44). 
Asheim, B.T. and Isaksen, A. (2002). 'Regional innovation systems: the integration of local 'sticky'and global 'ubiquitous' knowledge'. The Journal of Technology Transfer 27 (1), pp.77-86. doi:10.1023/A:101310070.

Asheim, B. T. et al. (2011). 'Regional Innovation Systems: Theory, Empirics and Policy Regional Innovation Systems : Theory, Empirics and Policy’ Regional studies, 45(7), pp.875-891 10.1080/00343404.2011.596701.

Audretsch, D. B. et al. (2019). 'Entrepreneurial ecosystems: economic, technological, and societal impacts', The Journal of Technology Transfer,44(2), pp. 313-325. doi: 10.1007/s10961-0189690-4.

Audretsch, D. B. and Belitski, M. (2017). 'Entrepreneurial ecosystems in cities: establishing the framework conditions', Journal of Technology Transfer, 42(5), pp. 1030-1051. doi: 10.1007/s10961-016-9473-8.

Auerswald, P. E. and Dani, L. (2017). 'The adaptive life cycle of entrepreneurial ecosystems: the biotechnology cluster', Small Business Economics, 49(1), pp.97-117. doi.org/10.1007/s11187017-9869-3.

Autio, E. et al. (2014). 'Entrepreneurial innovation: The importance of context', Research Policy, 43(7), pp.1097-1108. doi.org/10.1016/j.respol.2014.01.015

Autio, E. et al. (2018). 'Digital affordances, spatial affordances, and the genesis of entrepreneurial ecosystems', Strategic Entrepreneurship Journal, 12(1), pp.72-95. doi: 10.1002/sej.1266.

Berger, E. S. C. and Kuckertz, A. (2016). 'Female entrepreneurship in startup ecosystems worldwide', Journal of Business Research. Journal of Business Research, 69(11), pp.5163-5168. doi.org/10.1016/j.jbusres.2016.04.098.

Brown, R. and Mason, C. (2017a). 'Looking inside the spiky bits: a critical review and conceptualisation of entrepreneurial ecosystems', Small Business Economics, 49(1), pp.11-30. doi: 10.1007/s11187-017-9865-7.

Brown, R. and Mawson, S. (2016b). 'The geography of job creation in high growth firms : the implications of growing abroad' Environment and Planning C: Government and Policy, 34, pp. 207-227. doi: 10.1177/0263774X15614152.

Brown, R., Mason, C. and Mawson, S. (2014). 'Increasing "The Vital 6 Percent": Designing Effective Public Policy to Support High Growth Firms’, Nesta working paper doi: ISSN 2050-9820.

Bruns, K. et al. (2017). 'Searching for the existence of entrepreneurial ecosystems: a regional crosssection growth regression approach', Small Business Economics, 49(1), pp.31-54. doi: 10.1007/s11187-017-9866-6.

Carayannis, E. G. et al. (2018). 'The ecosystem as helix: an exploratory theory-building study of regional co-opetitive entrepreneurial ecosystems as Quadruple/Quintuple Helix Innovation Models', $R$ and D Management, 48(1), pp.148-162. doi.org/10.1111/radm.12300. 
Carayannis, E. G., Provance, M. and Grigoroudis, E. (2016). 'Entrepreneurship ecosystems: an agentbased simulation approach', Journal of Technology Transfer, 41(3), pp.631-653. doi.org/10.1007/s10961-016-9466-7.

Carlsson, B. (2006). 'Internationalization of innovation systems: A survey of the literature', Research Policy, 35(1), pp.56-67. doi: 10.1016/j.respol.2005.08.003.

Colombelli, A. et al. (2014). 'High Growth Firms and Technological Knowledge: Do gazelles follow exploration or exploitation strategies ? Industrial and Corporate Change, 23(1), pp.261-291. hal00666707.

Cohen, B. (2006). 'Sustainable valley entrepreneurial ecosystems', Business Strategy and the Environment, 15(1), pp1-14. 1-14. doi.org/10.1002/bse.428.

Coad, A. et al. (2014). 'High-growth firms: Introduction to the special section', Industrial and Corporate Change, 23(1), pp.91-112. https://doi.org/10.1093/icc/dtt052.

Colombo, M. G. et al. (2019). 'The governance of entrepreneurial ecosystems', Small Business Economics, 52(2), ,pp.419-428. doi: 10.1007/s11187-017-9952-9.

Cooke, P. (2001a). 'Regional innovation systems, clusters, and the knowledge economy'. Industrial and corporate change, 10(4), pp.945-974. doi.org/10.1093/icc/10.4.945.

Cooke, P. (2016b). 'The virtues of variety in regional innovation systems and entrepreneurial ecosystems'. Journal of Open Innovation: Technology, Market, and Complexity, 2(3), pp.13. doi.org/10.1186/s40852-016-0036-X.

Cooke, P. and Leydesdorff, L. (2006). 'Regional development in the knowledge-based economy: The construction of advantage', The Journal of Technology Transfer, 31(1), pp.5-15. doi.org/10.1007/s10961-005-5009-3

Cooke, P., Uranga, M. G., and Etxebarria, G. (1997). 'Regional innovation systems: Institutional and organisational dimensions', Research policy, 26(4-5), pp.475-491. doi.org/10.1016/S00487333(97)00025-5.

Costa, E., Soares, A. L. and de Sousa, J. P. (2016). 'Information, knowledge and collaboration management in the internationalisation of SMEs: a systematic literature review', International Journal of Information Management, 36(4), pp.557-569. doi.org/10.1016/j.ijinfomgt.2016.03.007.

Cowell, M., Lyon-Hill, S. and Tate, S. (2018) 'It takes all kinds: understanding diverse entrepreneurial ecosystems', Journal of Enterprising Communities, 12(2), pp.178-198. doi: 10.1108/JEC-082017-0064.

Daunfeldt, S. O., Elert, N., and Johansson, D. (2014). 'The economic contribution of high-growth firms: Do policy implications depend on the choice of growth indicator?', Journal of Industry, Competition and Trade, 14(3), pp.337-365. doi.org/10.1007/s10842-013-0168-7. 
Davidsson, P., Delmar, F., and Wiklund, J. (2006). 'Entrepreneurship and the Growth of Firms'. Edward Elgar Publishing.

Denyer, D., and Tranfield, D. (2009). 'Producing a systematic review', In D. A. Buchanan \& A. Bryman (Eds.), The Sage handbook of organizational research methods, pp. 671-689. Sage Publications Ltd.

Denyer, D., Tranfield, D. and Van Aken, J. E. (2008). 'Developing design propositions through research synthesis', Organization Studies, 29(3), pp.393-413. doi: 10.1177/0170840607088020.

Du, J. and Temouri, Y. (2015). 'High-growth firms and productivity: evidence from the United Kingdom', Small Business Economics, 44(1), pp. 123-143. doi: 10.1007/s11187-014-9584-2.

Edquist, C. (1997). 'Systems of innovation: technologies, institutions, and organizations' Psychology Press.

Etzkowitz, H. (2003). 'Innovation in innovation: The Triple Helix of university-industry-government relations', Social Science Information, 42(3), pp. 293-337. doi: 10.1177/05390184030423002.

Feld, B. (2012). 'Startup communities: Building an entrepreneurial ecosystem in your city'. John Wiley \& Sons.

Fernández, M. T., Blanco, F. J. and Cuadrado, J. R. (2015). 'Business incubation : innovative services in an entrepreneurship ecosystem’, The Service Industries Journal, 35(14), pp.783800. https://doi.org/10.1080/02642069.2015.1080243

Freel, M. S. (2003). 'Sectoral patterns of small firm innovation, networking and proximity', Research policy, 32(5), pp.751-770. doi:10.1016/S0048-7333(02)00084-7.

Friar, J. H. and Meyer, M. H. (2003). 'Entrepreneurship and Start-Ups in the Boston Region: Factors Differentiating High-Growth Ventures from Micro-Ventures', Small Business Economics, 21(2), pp.145-152. doi: 10.1023/A:1025045828202.

Goswami, K., Mitchell, J. R. and Bhagavatula, S. (2018). 'Accelerator expertise: Understanding the intermediary role of accelerators in the development of the Bangalore entrepreneurial ecosystem', Strategic Entrepreneurship Journal, 12(1), pp.117-150. doi: 10.1002/sej.1281.

Haltiwanger, J., Jarmin, R. S., and Miranda, J. (2013). 'Who creates jobs? Small versus large versus young'. Review of Economics and Statistics, 95(2), 347-361. Published by: The MIT Press.

Henrekson, M. and Johansson, D. (2009) 'Competencies and institutions fostering High-growth firms', Foundations and Trends in Entrepreneurship, 5(1), pp.1-80. doi: 10.1561/0300000026.

Henrekson, M. and Johansson, D. (2010) 'Gazelles as job creators: A survey and interpretation of the evidence’, Small Business Economics, 35(2), pp.227-244. doi: 10.1007/s11187-009-9172-z.

Hölzl, W., and Friesenbichler, K. (2010). 'High-growth firms, innovation and the distance to the frontier'. Economics Bulletin, 30(2), pp.1016-1024. doi 10.1007/s11187-009-9172-z. 
Isenberg, D. (2011). 'The entrepreneurship ecosystem strategy as a new paradigm for economy policy: principles for cultivating entrepreneurship'. Babson Entrepreneurship Ecosystem Project, Babson College, Babson Park: MA.

Isenberg, D. (2010a). 'How to start an entrepreneurial revolution'. Harvard business review, 88(6), pp.40-50.

Isenberg, D. (2014b). 'What an entrepreneurship ecosystem actually is'. Harvard Business Review, 5, pp.1-7.

Iyer, C. G. (2016). 'Impact of entrepreneur on the sectoral system of innovation: Case study of the Indian crude oil refining industry', Technological Forecasting and Social Change, 102, pp.102111. doi: 10.1016/j.techfore.2015.02.019.

Kshetri, N. (2014). 'Developing successful entrepreneurial ecosystems: Lessons from a comparison of an Asian tiger and a Baltic tiger', Baltic Journal of Management, 9(3), pp.330-356. doi: 10.1108/BJM-09-2013-0146.

Lee, N. (2014). 'What holds back high-growth firms? Evidence from UK SMEs', Small Business Economics, 43(1), pp.183-195. doi: 10.1007/s11187-013-9525-5.

Letaifa, S. B., \& Rabeau, Y. (2013). 'Too close to collaborate? How geographic proximity could impede entrepreneurship and innovation',Journal of Business Research, 66(10), pp.2071-2078. doi.org/10.1016/j.jbusres.2013.02.033.

Liberati, et al. (2009). 'The PRISMA statement for reporting systematic reviews and meta-analyses of studies that evaluate health care interventions: explanation and elaboration'. Annals of internal medicine, 151(4), pp.W-65.

Littunen, H. and Tohmo, T. (2003) 'The High Growth in New Metal-Based Manufacturing and Business Service Firms in Finland', Small Business Economics, 21(2), pp. 187-200. doi: 10.1023/A:1025014427294.

Lopez-Garcia, P. and Puente, S. (2012) 'What makes a high-growth firm? A dynamic probit analysis using Spanish firm-level data', Small Business Economics, 39(4), pp. 1029-1041. doi: 10.1007/s11187-011-9321-z.

Lundvall, B. A. (1992a). 'National systems of innovation: towards a theory of innovation and interactive learning' The Learning Economy and the Economics of Hope, p.85.

Lundvall, B. Å. (1998b). 'Why study national systems and national styles of innovation?'. Technology analysis \& strategic management, 10(4), pp.403-422. doi:10.1080/09537329808524324.

Lundvall, B. A. (2007). 'National innovation systems - Analytical concept and development tool', Industry and Innovation, 14(1), pp. 95-119. doi: 10.1080/13662710601130863.

Lundvall, B. A., et al. (2002). 'National systems of production, innovation and competence building. Research policy, 31(2), pp.213-231. doi:10.1016/S0048-7333(01)00137-8 
Mack, E. and Mayer, H. (2016) 'The evolutionary dynamics of entrepreneurial ecosystems', Urban Studies, 53(10), pp.2118-2133. doi: 10.1177/0042098015586547.

Malecki, E. J. (2018a). 'Entrepreneurship and entrepreneurial ecosystems', Geography Compass, 12(3), pp.1-21. doi: 10.1111/gec3.12359.

Mallett, R. et al. (2012). 'The benefits and challenges of using systematic reviews in international development research', Journal of Development Effectiveness, 4(3), pp.445-455. doi: 10.1080/19439342.2012.711342.

Maroufkhani, P., Wagner, R. and Wan Ismail, W. K. (2018). 'Entrepreneurial ecosystems: a systematic review', Journal of Enterprising Communities, 12(4), pp.545-564. doi: 10.1108/JEC-03-20170025.

Marques, J. P. C., Caraça, J. M. G. and Diz, H. (2006). 'How can university-industry-government interactions change the innovation scenario in Portugal? - The case of the University of Coimbra', Technovation, 26(4), pp.534-542. doi: 10.1016/j.technovation.2005.04.005.

Mason, C. and Brown, R. (2013). 'Creating good public policy to support high-growth firms', Small Business Economics, 40(2), pp.211-225. doi: 10.1007/s11187-011-9369-9.

Mason, C., \& Brown, R. (2014b). 'Entrepreneurial ecosystems and growth oriented entrepreneurship' Final Report to OECD, Paris, pp.30(1), 77-102.

Miller, D. J. and Acs, Z. J. (2017). 'The campus as entrepreneurial ecosystem: the University of Chicago’, Small Business Economics, 49(1), pp.75-95. doi: 10.1007/s11187-017-9868-4.

Muldoon, J., Bauman, A. and Lucy, C. (2018). 'Entrepreneurial ecosystem: do you trust or distrust?', Journal of Enterprising Communities, 12(2), pp.158-177. doi: 10.1108/JEC-07-2017-0050.

Nelson, R. (1993). 'National innovation systems: a comparative analysis' Oxford University Press on Demand.

Nambisan, S. and Baron, R. A. (2013). 'Entrepreneurship in innovation ecosystems: Entrepreneurs' self-regulatory processes and their implications for new venture success', Entrepreneurship: Theory and Practice, 37(5), pp.1071-1097. doi: 10.1111/j.1540-6520.2012.00519.x.

Nicotra, M. et al. (2018). 'The causal relation between entrepreneurial ecosystem and productive entrepreneurship: a measurement framework', Journal of Technology Transfer, 43(3), pp.640673. doi: 10.1007/s10961-017-9628-2.

OECD (2010). 'High-Growth Enterprises: What governments can do to make a difference', $O E C D$ Studies on SMEs and entrepreneurship, OECD publishing. http://dx.doi/10.1787/9789264048782.en.

Oh, D. S. et al. (2016). 'Innovation ecosystems: A critical examination', Technovation, 54, pp.1-6. doi: 10.1016/j.technovation.2016.02.004. 
Öner, M. A. and Kunday, Ö. (2016). 'A study on Schumpeterian and Kirznerian entrepreneurship in Turkey: 2006-2013, Technological Forecasting and Social Change, 102, pp.62-71. doi.org/10.1016/j.techfore.2015.09.005.

Pitelis, C. (2012). 'Clusters, entrepreneurial ecosystem co-creation, and appropriability: A conceptual framework', Industrial and Corporate Change, 21(6), pp.1359-1388. doi: 10.1093/icc/dts008.

Pittz, T. G. and Hertz, G. (2018). 'A relational perspective on entrepreneurial ecosystems: The role and sustenance of the entrepreneurship center', Journal of Enterprising Communities, 12(2), pp.220 231. doi: 10.1108/JEC-10-2017-0081.

Qian, H. and Acs, Z. J. (2013). 'An absorptive capacity theory of knowledge spillover entrepreneurship', Small Business Economics, 40(2), pp.185-197. pp. 185-197. doi: 10.1007/s11187-011-9368-x.

Qian, H., Acs, Z. J. and Stough, R. R. (2013). 'Regional systems of entrepreneurship: The nexus of human capital, knowledge and new firm formation', Journal of Economic Geography, 13(4), pp. 559-587. doi: 10.1093/jeg/lbs009.

Rodríguez-Pose, A. (2013). 'Do institutions matter for regional development?' Regional studies, 47(7), pp.1034-1047. doi.org/10.1080/00343404.2012.748978.

Roundy, P. (2018). 'Social Entrepreneurship and Entrepreneurial Ecosystems: Complementary or Disjointed Phenomena?, International Journal of Social Economics, 44 (9), pp.1252-1267. doi.org/10.1108/IJSE-02-2016-0045.

Roundy, P. T. (2017). 'Hybrid organizations and the logics of entrepreneurial ecosystems', International Entrepreneurship and Management Journal, 13(4), pp.1221-1237. doi: 10.1007/s11365-017-0452-9.

Roundy, P. T., Bradshaw, M. and Brockman, B. K. (2018). 'The emergence of entrepreneurial ecosystems: A complex adaptive systems approach', Journal of Business Research, 86, pp. 1-10. doi: 10.1016/j.jbusres.2018.01.032.

Segarra, A. and Teruel, M. (2014). 'High-growth firms and innovation: An empirical analysis for Spanish firms', Small Business Economics, 43(4), pp. 805-821. doi: 10.1007/s11187-014-9563-7.

Scaringella, L. and Radziwon, A. (2018). 'Innovation, entrepreneurial, knowledge, and business ecosystems: Old wine in new bottles?', Technological Forecasting and Social Change, pp. 5987. doi: 10.1016/j.techfore.2017.09.023.

Schøtt, T. and Jensen, K. W. (2016). 'Firms' innovation benefiting from networking and institutional support: A global analysis of national and firm effects', Research Policy, 45(6), pp.1233-1246. doi: 10.1016/j.respol.2016.03.006.

Schreyer, P. (2000). High-growth firms and employment. OECD Science, Technology and Industry Working Papers 2000/03.doi.org/10.1787/18151965. 
Shane, S. (2009). 'Why encouraging more people to become entrepreneurs is bad public policy', Small Business Economics, 33(2), pp.141-149. doi: 10.1007/s11187-009-9215-5.

Sharif, N. (2006). 'Emergence and development of the National Innovation Systems concept', Research policy, 35(5), pp.745-766. doi: 10.1016/j.respol.2006.04.00.

Smallbone, D., Leigh, R. and North, D. (1995). 'The characteristics and strategies of high growth SMEs', International Journal of Entrepreneurial Behaviour \& Research, 1(3), pp.44-62. doi: 10.1108/13552559510100657.

Sohn, D. W. and Kenney, M. (2007). 'Universities, Clusters, and Innovation Systems: The Case of Seoul, Korea', World Development, 35(6), pp.991-1004. doi: 10.1016/j.worlddev.2006.05.008.

Spender, J. C. et al. (2017). 'Startups and open innovation: a review of the literature', European Journal of Innovation Management, 20(1), pp. 4-30. doi: 10.1108/EJIM-12-2015-0131.

Spigel, B. (2017). 'The Relational Organization of Entrepreneurial Ecosystems', Entrepreneurship Theory and Practice, 41(1), 49-72. doi.org/10.1111/etap.12167.

Spigel, B. and Harrison, R. (2018). 'Toward a process theory of entrepreneurial ecosystems', Strategic Entrepreneurship Journal, 12(1), pp. 151-168. doi: 10.1002/sej.1268.

Stam, E. (2015). 'Entrepreneurial Ecosystems and Regional Policy: A Sympathetic Critique', European Planning Studies, 23(9), pp. 1759-1769. doi: 10.1080/09654313.2015.1061484.

Stangler, D. (2010). 'High-growth firms and the future of the American economy'. Available at SSRN 1568246. DOI:10.2139/ssrn.1568246.

Suresh, J. and Ramraj, R. (2012). 'Entrepreneurial ecosystem: Case study on the influence of environmental factors on entrepreneurial success, European Journal of Business and Management, 4(16), 95-101.

Terjesen, S., Bosma, N. and Stam, E. (2016). 'Advancing Public Policy for High-Growth, Female, and Social Entrepreneurs', Public Administration Review, 76(2), pp. 230-239. doi: 10.1111/puar.12472.

Theodoraki, C., Messeghem, K. and Rice, M. P. (2018). 'A social capital approach to the development of sustainable entrepreneurial ecosystems: an explorative study', Small Business Economics. Small Business Economics, 51(1), pp. 153-170. doi: 10.1007/s11187-017-9924doi:10.1007/s11187-017-9924-0.

Thompson, T. A., Purdy, J. M. and Ventresca, M. J. (2018). 'How entrepreneurial ecosystems take form: Evidence from social impact initiatives in Seattle', Strategic Entrepreneurship Journal, 12(1), pp. 96-116. doi: 10.1002/sej.1285.

Tranfield, D., Denyer, D. and Smart, P. (2003). 'Towards a Methodology for Developing EvidenceInformed Management Knowledge by Means of Systematic Review', British Journal of Management, 14(3), pp. 207-222. doi: 10.1111/1467-8551.00375. 
Vargo, S. L., Wieland, H. and Akaka, M. A. (2015). 'Innovation through institutionalization: A service ecosystems perspective', Industrial Marketing Management,44, pp.63-72.

doi:10.1016/j.indmarman.2014.10.008.

Velt, H., Torkkeli, L. and Saarenketo, S. (2018). 'The entrepreneurial ecosystem and born globals: the Estonian context', Journal of Enterprising Communities, 12(2), pp. 117-138. doi: 10.1108/JEC08-2017-0056.

Wohlin, C. (2014). 'Guidelines for snowballing in systematic literature studies and a replication in software engineering', In Proceedings of the 18th international conference on evaluation and assessment in software engineering (p. 38). ACM. doi:10.1145/2601248.2601268.

Wong, C. et al. (2012). 'Towards a theory of supply chain alignment enablers: A systematic literature review', Supply Chain Management, 17(4), pp. 419-437. doi: 10.1108/13598541211246567.

Yoon, H. et al. (2015). 'Entrepreneurship in East Asian Regional Innovation Systems: Role of social capital', Technological Forecasting and Social Change, 100, pp. 83-95. doi: 10.1016/j.techfore.2015.06.028.

Zahra, S. A. and Nambisan, S. (2012). 'Entrepreneurship and strategic thinking in business ecosystems', Business Horizons. 'Kelley School of Business, Indiana University', 55(3), pp. 219-229. doi: 10.1016/j.bushor.2011.12.004. 